Editorial：医療関連死原因究明と医療安全の新たな展開一一再教育を主とする行政指導制度 ——高 本 県 一 1

特集 I：基碿科学の進歩

難治性不整脈の遺伝子解析

蒔田直昌 3

RAAS の新たな展開

吉野拓哉, 名越智古ほか

特集 II：第76回日本循環器学会学術集会

1. 心エコー図診断の最新の知見と新たな展開

3D アデノシン負荷心エコー図法による心筋リスクエリアの同定

一一パラメトリックイメージングの有用性

高野真澄 17

僧帽弁弁下構造に基づいた機能性僧帽弁逆流に対する外科治療

一一術中三次元経食道エコー図の役割

尾長谷喜久子 23

\title{
2. 冠血行再建の最前線
}

左主幹部病変を有する患者に対する冠動脈バイパス術の長期成績

非保護左主幹部病変に対する DES を用いた PCI と CABG の長期成績の比較

3.「蘇生と敖急心血管治癔の国際ガイドライン 2010」を活かす

..福 康志, 門田一繁 ほか 39

急性心筋梗塞による心停止後症候群に対する緊急 PCI の効果

院内心停止における心不全に関する検討

立花栄三, 長尾 建 ほか 49

4. 術後遠隔期の先天性心疾患の管理

成人先天性心疾患の診療体制の確立に向けて

横山広行，野々木宏 54

成人先天性心疾患術後症例の頻脈性不整脈に対するカテーテルアブレーション

および植込み型除細動器植え込み術

白石 公, 丹羽公一郎 61

\section{ステージロ 心不全治癔の現状と課通}

連続流ポンプの左室補助人工心䐵（LVAD）植え込みに際して知っておくべきことは何か?

ステージ D 心不全に対する補助人工心臟の役割

絹川弘一郎 77

坂口太一 83

\section{回值環器学2012年の進歩}

小児循環器学研究の進歩

動脈硬化研究の進歩

心臓病学研究の進歩

高血圧治療の進歩

心電学研究の進歩

心不全研究の進歩

真中哲之 71

症例検討：労作により誘発される冠攀縮性狭心症を伴った閉塞性肥大型心筋症の 1 例

宇都宮裕人，岩 崎 年高ほか 119

田門医トレーニング問題 四豊田

茂, 伊波 秀ほか/回伊勢孝之, 佐田政隆 128

日日本のパイオニア

大動脈解離に対するステントグラフト

加藤 雅 明 135

口循環器專門医活動と現況

徳島赤十字病院

溑岡建城 90

枇榔貞 利，佐々木 淳 94

平井忠和, 水牧功一ほか 98

土肥靖明，木村玄次郎 103

中谷晴昭, 松本明郎 108

福本義弘, 下川宏明 113

循環器病専門施設見学

棉原記念病院

宮崎市郡医師会病院

吉田路加 147

学会印象記

影嶋健二 152

欧州心臓学会議 (ESC2012)

添木 武 156

米国心臓協会 (AHA2012)

市田蕗子 163

専門医 NEWS／循環器専門医研修施設，研修関連施設／学術集会日程

編集後記

新 博 次 186 